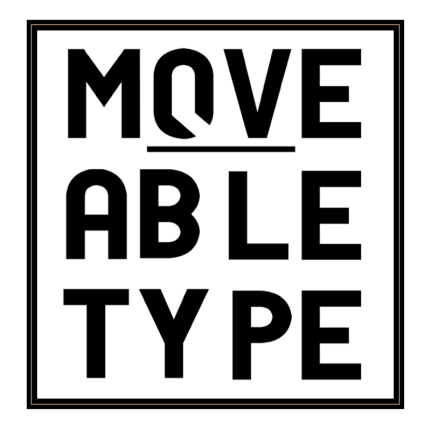

'The Ties That Bind: Virginia Woolf, Leslie Stephen, and Ancestral Mountains'

Author[s]: Catherine Dent

Source: Moveable Type, Vol.13, 'Ambience' (2021)

DOI: 10.14324/111.1755-4527.118

MoveableType is a Graduate, Peer-Reviewed Journal based in the Department of English at UCL.

(C) 2021 Catherine Dent. This is an Open Access article distributed under the terms of the Creative Commons Attribution License (CC-BY) 4.0https:/creativecommons,org/licenses/by/4.0/, which permits unrestricted use, distribution, and reproduction in any medium, provided the original author and source are credited. 


\section{The Ties That Bind: Virginia Woolf, Leslie Stephen, and Ancestral Mountains}

Catherine Dent

This article examines Virginia Woolf's late short story, 'The Symbol', which takes as its focus the problem of writing the mountain landscape. Not only is the mountain vulnerable to misrepresentation in being "elevated" to the function of a literary symbol, for Woolf it is also freighted with the overbearing weight of her father's mountaineering legacy, both on the slopes and on the written page. Read in the light of the Alpine exploits of her father (Sir Leslie Stephen), this article presents 'The Symbol' not as a minor work on the peripheries of the writer's oeuvre, but as an important vehicle through which Woolf is able to confront not only her ambivalent relationship with her late father and his legacy, but also the ontological complexities of representing the mountain in creative fiction.

In The Living Mountain (c. 1945), Nan Shepherd voices her suspicion that the love of mountaineering - the urge to "get high", as it were - may well 'have a physiological origin.' Those who find themselves drawn to mountain peaks, she speculates, are so lured because they 'have the particular bodily make-up that functions at its most free and most live upon heights'. ${ }^{2}$ If this 'bodily make-up' can be attributed to one's genetics, however, it would seem that Virginia Woolf did not inherit her father's passion for Alpinism. More accustomed to ascending mountains on muleback or in a motor bus, it may seem unsurprising that in 'The Symbol' (c. 1941) - which boasts the dubious distinction of possibly being the last short story Woolf ever wrote - an Alpine peak modelled on the Matterhorn is depicted from the safe distance of a comfortable hotel room. ${ }^{3}$ This article, however, will hope to show that Woolf's hotel room in 'The Symbol' is not in fact 'shut from infinities', to quote Shepherd once more. ${ }^{4}$ Rather, it will be argued, the mountain acts as the story's central hermeneutic knot, on which Woolf's theoretical musings on ecological connection and the (in)sufficiency of language are

\footnotetext{
${ }^{1}$ Nan Shepherd, The Living Mountain (Edinburgh: Canongate, 2011), p. 7.

${ }^{2}$ Ibid.

${ }^{3}$ For Woolf's account of ascending Mont Serrat in a motor bus, see Virginia Woolf, 'To Duncan Grant', in Selected Letters, ed. by Joanne Trautmann Banks (London: Vintage, 2008), pp. 76-77 (8 September 1912).

${ }^{4}$ Nan Shepherd, 'Fires', in In the Cairngorms (Cambridge: Galileo Publishers, 2015), 1. 19.
} 
centred, and through which her own ambivalent relationship with her father and his mountaineering legacy is refracted.

In comparison with other works by Woolf, relatively little critical ink has been spilled over 'The Symbol': Abbie Garrington has read it in light of epistolary practice, Julia Briggs has turned her attention to Woolf's deft manipulation of perspective, and both critics have noted the metafictional dimension which Woolf's proxy female (letter) writer lends the story. Catherine W. Hollis has begun to draw out the links between this late story of Woolf's and 'her father's Alpine heritage', and she has also touched on some of the ways in which Leslie Stephen's love of mountaineering informed what she calls his 'ecological ethics' - that is, his understanding of the world as an interconnected 'biotic community', humanity's membership of which entails both 'rights and responsibilities' - and how such modes of thought came to influence his youngest daughter. ${ }^{5}$ While this article will expand on some of the points raised by Hollis, it will differ with her psychobiographical speculation that Woolf's life - and, implicitly, her work - could have been improved had she 'taken up mountain climbing' and thereby 'found in the activity what her father did: mental and physical vitality, friendship, and pleasure. ${ }^{6}$ Rather, this article will contend that while 'The Symbol' is freighted with the legacy of her father, its triumph lies in Woolf's ability to simultaneously take her own stance on the vexed issue of writing the mountain (a topic on which Leslie Stephen had made his feelings very clear), while replicating her father's youthful fervour for discovering new routes of ascent in her commitment to continually charting new territory in her writing.

\section{Writing the Mountain}

On $22^{\text {nd }}$ June 1937, while she was working on Three Guineas, Woolf wrote in her diary:

I would like to write a dream story about the top of a mountain. Now why? About lying in the snow; about rings of colour; silence; and the solitude. I can't though. But shan't I, one of these days indulge myself in some short releases into that world? Short now for ever. No more long

\footnotetext{
${ }^{5}$ Catherine W. Hollis, 'Virginia Woolf as Mountaineer', in Virginia Woolf and the Natural World: Selected Papers of the Twentieth Annual International Conference on Woolf, ed. by Kristin Czarnecki and Carrie Rohman (Liverpool: Liverpool University Press, 2011), pp. 184-9o (p. 186); Catherine W. Hollis, 'Leslie Stephen's Science of (Ecological) Ethics', in Virginia Woolf and the Common(wealth) Reader: Selected Papers from the Twenty-Third Annual International Conference on Virginia Woolf, ed. by Helen Wussow and Mary Ann Gillies (Clemson: Clemson University Digital Press, 2014), pp. 45-49 (p. 48).

${ }^{6}$ Hollis, 'Virginia Woolf as Mountaineer', p. 190.
} 
grinds: only sudden intensities. [...] If I could think out another adventure. [...] And it's useless to repeat my old experiments: they must be new to be experiments. ${ }^{7}$

Judging from this diary entry alone, one might be tempted to think of Woolf's story 'The Symbol' - the 'dream story about the top of a mountain' she would eventually write shortly before her death - as a lightweight, frivolous piece of fiction within her oeuvre, a distraction, self-indulgent but fun, from the 'long grind' of a serious work such as Three Guineas. Upon reading 'The Symbol', however, the reader can appreciate that the writing of the 'dream story about the top of a mountain' is a task beset with difficulties. In 'The Symbol', Woolf presents the challenge of writing about mountains in a figurative, descriptive manner - without resorting to cliché - as a test of literary skill: 'She had written the mountain was a symbol. But of what? [...] We are always climbing to some height; that was the cliché. But it did not represent what was in her mind's eye; after seeing through her glasses the virgin height.'8 George Mallory - the famous mountaineer painted by Duncan Grant and adored by Lytton Strachey - notes that the writers of most accounts of climbing mountains restrict themselves to the purely factual, as 'for the literary expression, it is too difficult to handle.' ${ }^{9}$ As Woolf suggests here, hackneyed readings of the mountain as a 'symbol of effort' provide a descriptive crutch for the letter writer, which she must ultimately reject, as Woolf expresses her dissatisfaction with such worn out set phrases in a holograph draft of the story: 'But that was unfitting. The other thing that this peak represented was not at all a cliché: in fact it was something that far from running into ink spontaneously, remained almost unspeakable even to herself. ${ }^{10}$

It is worth noting that such sentiments echo Leslie Stephen's aversion for narratives that seek 'to convert [mountains] into allegories about man's highest destinations and aspirations', as well as his suspicions of the insufficiency of 'feeble language' to capture the experience of mountaineering. 'The wonders of the Alps,' Stephen cautions, 'cannot be put down in black and white on a page of 5 inches by 7', and in 'Sunset on Mont Blanc', rather than describing the sunset, he assures his readers that the easiest way of obtaining the

\footnotetext{
${ }^{7}$ Virginia Woolf, $A$ Writer's Diary: Being Extracts from the Diary of Virginia Woolf, ed. by Leonard Woolf (London: Persephone Books, 2011), p. 283.

${ }^{8}$ Virginia Woolf, 'The Symbol', in A Haunted House: The Complete Shorter Fiction, ed. by Susan Dick (London: Vintage, 2003), pp. 282-84 (pp. 282-83).

${ }^{9}$ For more information on Lytton Strachey's feelings for George Mallory, see Michael Holroyd, Lytton Strachey: A Critical Biography, Vol. 1: The Unknown Years (London: Heinemann, 1967), pp. 441-42; George Leigh Mallory, The Mountaineer as Artist', in Climbing Everest: The Complete Writings of George Leigh Mallory, ed. by Peter Gillman (London: Gibson Square, 2010), pp. 15-28 (p. 19).

${ }^{10}$ Virginia Woolf, Holograph draft version of 'The Symbol', partially reproduced in 'Notes' by Susan Dick (ed.), A Haunted House: The Complete Shorter Fiction (London: Vintage, 2003), pp. 305-06 (p. 305).
} 
impression is to follow in my steps' ${ }^{11}$ According to this mode of thought, to theorise the mountain as a symbol - to reduce it to a fixed, knowable meaning - is to etherealise the mountain, rather than confronting 'the epistemological problem of mountains' and endeavouring to 'see the mountain in itself as it really is', as Hollis states was Stephen's resolution. ${ }^{12}$ Thus, for Stephen, to read the mountain as a symbol is to promote it to a 'higher' function within the narrative's intellectual framework, and by so using the mountain to signify a 'higher' meaning than one might credit inert rock, the epistemological materiality of the mountain is subjugated to the furtherance of this 'higher' meaning. As Woolf herself puts it, '[a] cloud then would do instead of the mountain' to symbolise the heights for which man eternally strives. ${ }^{13}$

While Stephen dismisses the presentation of the mountain as a symbol, however, it should be noted that he offers the writer no alternative mode of expression. Stephen's pronouncements on the proper way of experiencing the mountain are laid down as though he had fetched them from the top of Mount Sinai. Woolf famously stated that, had her father lived longer, 'his life would have entirely ended mine' in as much as it would have strangled her own literary ambitions, making a career as a writer 'inconceivable. ${ }^{14}$ Indeed, if we read Woolf's short story in light of her gloomy prognostications in the event of her father's longevity, the way in which the letter writer's statement "[t]he mountain [...] is a symbol..." tapers off into elliptical inarticulacy may suggest that the overbearing authority of 'Stephen's Alpine legacy' effectively silences his non-climber daughter. ${ }^{15}$

Indeed, as Woolf writes elsewhere in her fictional works of the inadequacy and frustrating obduracy of language (recall, for instance, Lily Briscoe's complaint in To the Lighthouse (1927) that '[w]ords fluttered sideways and struck the object inches too low'), the challenge of inscribing the mountain in 'The Symbol' seems to be freighted with especial significance as a means of reconnecting with her father's mountaineering legacy, both on the slopes and on the written page. ${ }^{16}$ Direct evidence for what Hollis terms 'Stephen's Alpine legacy' within 'The Symbol' can be inferred from Woolf's allusion to Melchior Anderegg

\footnotetext{
${ }^{11}$ Leslie Stephen, 'Mr. Whymper's "Scrambles amongst the Alps"', Macmillan's Magazine, 24, 142 (1871), 304-11 (p. 305); Leslie Stephen, 'The Regrets of a Mountaineer', in The Playground of Europe (Cambridge: Cambridge University Press, 2013), pp. 303-39 (p. 308); Leslie Stephen, 'Sunset on Mont Blanc', in The Playground of Europe (Cambridge: Cambridge University Press, 2013), pp. 257-78 (p. 268).

${ }^{12}$ Hollis, 'Virginia Woolf as Mountaineer', p. 187.

${ }^{13}$ Woolf, 'The Symbol', p. 283.

${ }^{14}$ Virginia Woolf, as quoted by Hollis, 'Virginia Woolf as Mountaineer', p. 188.

${ }^{15}$ Hollis, 'Virginia Woolf as Mountaineer', p. 184.

${ }^{16}$ Virginia Woolf, To the Lighthouse, ed. by David Bradshaw (Oxford: Oxford University Press, 2006), p. 146.
} 
(Stephen's Alpine guide) in the surname of the hotel owner, Herr Melchior, and her familiarity with the culture of nineteenth century mountaineering, as suggested by her reference to the deaths of 'four men' in the 1865 Matterhorn Disaster. ${ }^{17}$ Indeed, as Stephen reviewed Edward Whymper's account of the fateful first ascent of the Matterhorn for Macmillan's Magazine in 1871, the textual trail of this accident links Stephen to this 'haunted' mountain, albeit only tangentially. ${ }^{18}$ It is therefore noteworthy that 'Stephen's Alpine legacy' is not just distinguished by his climbing prowess, but also by his literary output as one of the leading mountaineers of his generation. Though Woolf opens her commemorative essay on her father by stating that Stephen's 'feats on the river and on the mountains had been won before [his children] were born', she goes on to write that the memory of her father's 'great days' was preserved by such '[r]elics' as 'rusty alpenstocks' and a 'silver cup', and by the 'stories he told to amuse his children of adventures in the Alps'. ${ }^{19}$ While it recalls the semiotic bedtime story Mrs Ramsay tells Cam of 'a beautiful mountain such as she had seen abroad' in To the Lighthouse, this image of Stephen spinning yarns 'of adventures in the Alps' reveals an interesting tension in his professed suspicion of the insufficiency of language. ${ }^{20}$ Stephen's willingness to relate his Alpine adventure stories to his children may imply he felt a greater freedom in the spoken word which he could not allow for himself or others in writing the mountain. Though Woolf herself was not an experienced mountaineer, one might speculate that her father's stories may have forged an association between narrative and the act of climbing a mountain for Woolf, and thus in writing 'The Symbol' she has, in one sense, followed in his footsteps.

\section{Father Mountain}

If Stephen was an inspiration to his daughter in her formative years, however, he could also be severe and controlling at times, and Woolf's relationship with him reflected this conflict. Thus the letter writer's association of the mountaintop with the death of a parent (in this case, her mother) and the freedom that death will bring may also forge another tie between 'The Symbol' and Woolf's relationship with her father. As Woolf's letter writer informs her unnamed addressee:

\footnotetext{
${ }^{17}$ Hollis, 'Virginia Woolf as Mountaineer', p. 186; Woolf, 'The Symbol', p. 282.

${ }^{18}$ Stephen, 'Mr Whymper's "Scrambles amongst the Alps"', p. 310.

19 Virginia Woolf, 'Leslie Stephen', in Selected Essays, ed. by David Bradshaw (Oxford: Oxford University Press, 2009), pp. 111-15 (pp. 111, 112).

${ }^{20}$ Woolf, To the Lighthouse, p. 93.
} 
I never told you [...] how I longed when the doctor came, that he should say, quite definitely, She cannot live another week. It was very prolonged; she lived eighteen months. The mountain just now reminded me how when I was alone, I would fix my eyes upon her death, as a symbol. I would think if I could reach that point - when I should be free - [...] I have never told anyone; for it seemed so heartless; I shall be at the top. ${ }^{21}$

Woolf's own mother, Julia Stephen, died of rheumatic fever, brought on by influenza, in 1895, when Virginia was just thirteen years old. Woolf later described her mother's death as 'the greatest disaster that could happen'. ${ }^{22}$ Leslie Stephen, on the other hand, died after a long battle with cancer, prolonged initially by his determination to cling onto life, which left his children exhausted and longing for 'anything to end this', as Woolf writes in a letter to her friend, Violet Dickinson. ${ }^{23}$ 'The waiting is intolerable', she confesses to Dickinson, 'If only it could be quicker!'24 Thus one might argue that Catherine W. Hollis is right to suggest that the mother dying of cancer in 'The Symbol' - like the dying Pargiter matriarch in The Years (1937) - serves 'as a transposition for Leslie Stephen' and his agonizingly protracted passing. ${ }^{25}$ In 'The Symbol', then, it is as though, to adapt Woolf's remark, recorded in her diary on 17 February 1922, she meant to write about solitude, only her family came breaking in as usual. 26

Yet even as Woolf longed for the freedom which her father's lingering death seemed to deny her, there are hints of filial affection among her correspondence with Dickinson at this time: while Stephen's illness makes 22 Hyde Park Gate seem increasingly prison-like 'the longer we live there \& wear fetters of association \& sentiment,' these fetters, 'painful to wear' as they are, are 'still more painful to break.' ${ }^{27}$ Woolf, Hermione Lee contends, compulsively 'wrote and rewrote her father all her life': 'She was in love with him, she was furious with him, she was like him, she never stopped arguing with him,' and this complicated mixture of love and guilt, grief and rage, is mediated through the haunting presence of the mountain in 'The Symbol'. ${ }^{28}$ If the mountain connotes freedom for Woolf's letter writer (a proxy-author, of sorts, as Garrington observes), we are also told in no

\footnotetext{
${ }^{21}$ Woolf, 'The Symbol', p. 283.

${ }^{22}$ Virginia Woolf, 'Reminiscences', in Moments of Being ed. by Jeanne Schulkind (London: Pimlico, 2002), pp. 1-30 (p. 11).

${ }^{23}$ Virginia Woolf, 'To Violet Dickinson', in Selected Letters, ed. by Joanne Trautmann Banks (London: Vintage, 2008), p. 14 (February 1904).

${ }^{24}$ Ibid; Virginia Woolf, as quoted by Hermione Lee, Virginia Woolf (London: Vintage, 1997), p. 172.

${ }^{25}$ Hollis, 'Virginia Woolf as Mountaineer', p. 188.

26 'I meant to write about death, only life came breaking in as usual.' Virginia Woolf, The Diary of Virginia Woolf, Volume II: 1920-1924, ed. by Anne Olivier Bell and Andrew MacNeilie (London: The Hogarth Press, 1978), p. 167.

${ }^{27}$ Virginia Woolf, as quoted by Lee, p. 172.

${ }^{28}$ Lee, p. 68.
} 
uncertain terms that its omnipresence disturbs her: 'One can see the mountain from every window. [...] I can assure you, I could shriek sometimes coming out of the one shop where they sell papers - we get them a week late - always to see that mountain.' ${ }^{29}$ 'Its looming presence is at once oppressive, yet longed for', as Briggs observes - just as Stephen's youngest daughter, in the immediate aftermath of his once desired death, would write to her old friend, 'Oh my Violet, I do want Father so.'3o

\section{Thinking Like a Mountain}

If, however, 'the Victorian worship of mountain settings' was 'embodied [...] by Leslie Stephen', as Catherine Lanone affirms, and as Thomas Hardy in his commemorative poem 'The Schreckhorn', written '[w]ith thoughts of Leslie Stephen', would seem to concur, then Stephen may also have provided a framework against which his modernist daughter could define herself through experimentation. ${ }^{31}$ Indeed, Woolf wrote in her diary that she intended the story to be a 'new' experiment, and her playful manipulation of perspective betrays a 'modern sense of fragmentation' by 'decentring the subject'. ${ }^{22}$ The cinematic close-up of the 'little dent on the top of the mountain' foregrounds the importance of nonstandard and even, as is the case here, of nonhuman perspectives in the story, allowing the reader a bird's eye view of the snow-capped peak even as Woolf writes: 'It was too high for breathing flesh or fur covered life.'33 Stephen's exhortation for us to 'follow in my steps' must necessarily fall on stony ground here, as Woolf takes us to heights humans cannot experience without the aid of technology - in this case, the letter writer's binoculars. This image of the letter writer using binoculars as a prosthetic of sorts in order to see to the top of the mountain underscores the limits of human dominance over the mountain, thus undermining what Mary Louise Pratt calls the 'Monarch-of-all-I-survey' posturing of the Romantic Rückenfigur. ${ }^{34}$ As Woolf

\footnotetext{
${ }^{29}$ Abbie Garrington, 'The Line that Binds: Climbing Narratives, Ropework and Epistolary Practice', in Modernism and Affect, ed. by Julie Taylor (Edinburgh: Edinburgh University Press, 2015), pp. 75-93 (p. 87); Woolf, 'The Symbol', p. 283.

30 Julia Briggs, Reading Virginia Woolf (Edinburgh: Edinburgh University Press, 2006), p. 186; Virginia Woolf, as quoted by Lee, p. 173.

${ }^{31}$ Catherine Lanone, “There is something unspeakable in these outposts" (PI): E. M. Forster's Problematic Poetics of Ascent', in Mountains Figured and Disfigured in the English-Speaking World, ed. by Françoise Besson (Newcastle Upon Tyne: Cambridge Scholars Publishing, 2010), pp. 358-71 (p. 369); Thomas Hardy, 'The Schreckhorn' (June 1897) $<$ http://www.poetryatlas.com/poetry/poem/573/the-schreckhorn.html > [accessed 20 February 2021].

${ }^{32}$ Lanone, pp. 369-70.

${ }^{33}$ Woolf, 'The Symbol', p. 282.

${ }^{34}$ Mary Louise Pratt, as quoted by Gillian Carter, "Domestic Geography' and the Politics of Scottish Landscape in Nan Shepherd's The Living Mountain', Gender, Place and Culture: A Journal of Feminist Geography, 8, 1 (2001), 25-36 (p. 29).
} 
pointedly deems the peak 'too high for breathing flesh or fur covered life', this space is explicitly designated as beyond human control.

In this sense, 'The Symbol' can be read in dialogue with Woolf's essay 'On Being Ill', in which Woolf states that, in illness, humans have the leisure to look to the sky just as the letter writer in 'The Symbol' does and to thus realise that the sky 'has nothing to do with human pleasure or human profit', or, as Shepherd puts it: 'it does nothing, absolutely nothing, but be itself.' ${ }^{35}$ Woolf's interest in decentring the human subject is therefore comparable to Aldo Leopold's notion of 'thinking like a mountain', which, as Timothy Clark explains, 'highlights the finite scope of human thought, its limitation, for instance, to stretches of time that would seem miniscule to a mountain. ${ }^{36}$ As Leopold himself writes: 'Only the mountain has lived long enough to listen objectively to the howl of a wolf.' ${ }^{77}$ In light of this, the letter writer's inability to pin down the symbolism of the mountain need not be read as a defeat, but rather as an openness to a plurality of meanings, or even to the possibility of a meaning that exists beyond human understanding. As Hollis observes that 'The Symbol' 'presents the mountain as an unsolvable problem, a crevasse that cannot be crossed', the real challenge of the mountain landscape in Woolf's story is not physical, but epistemological. ${ }^{3}$

If Woolf's writing can be credited with anticipating Leopold's notion of 'thinking like a mountain', then Stephen's work can claim a fifty-year precedent on that of his daughter, and one might well speculate that Woolf's own peculiar conceptualisation of ecological interconnection, her abiding sense 'that we $-[\ldots]$ all human beings - are connected with this; that the whole world is a work of art; that we are parts of the work of art', was informed by her father's Alpine philosophy. ${ }^{39}$ In the account Woolf wrote of her father in 1932 to mark the centenary of his birth, she mentions that Stephen himself considered 'Sunset on Mont Blanc' to be 'the best thing he ever wrote', and thus one might deduce that Woolf had in all probability read this essay, 'out of curiosity if nothing else', as Hollis suggests. ${ }^{40}$ Hollis also notes that it is in 'Sunset on Mont Blanc' that Stephen expounds his own answer to the task

\footnotetext{
${ }^{35}$ Virginia Woolf, 'On Being Ill', in Selected Essays, ed. by David Bradshaw (Oxford: Oxford University Press, 2009), pp. 101-10 (p. 105); Nan Shepherd, The Living Mountain (Edinburgh: Canongate, 2011), p. 23.

${ }^{36}$ Timothy Clark, The Cambridge Introduction to Literature and the Environment (Cambridge: Cambridge University Press, 2011), p. 78.

${ }^{37}$ Aldo Leopold, 'Thinking Like a Mountain', in A Sand County Almanac: And Sketches Here and There (London: Penguin, 2020), pp. 97-99 (p. 97).

${ }^{38}$ Hollis, 'Virginia Woolf as Mountaineer', p. 189.

${ }^{39}$ Virginia Woolf, 'Sketch of the Past', in Moments of Being, ed. by Jeanne Schulkind (London: Pimlico, 2002), pp. 78-16o (p. 85).

${ }^{40}$ Woolf, 'Leslie Stephen', p. 111; Hollis, 'Virginia Woolf as Mountaineer', p. 186.
} 
of 'thinking like a mountain' in a pair of open questions: 'Does not science teach us more and more emphatically that nothing which is natural can be alien to us who are part of nature? Where does Mont Blanc end, and where do I begin?'41 As Clark notes, Leopold's challenge to 'think like a mountain' appears a 'strictly nonsensical phrase' - how can one think like inert rock? - which should be read as a proposal for a shift in our habituated, anthropocentric modes of conceptualizing subjectivity, towards a recognition that, as Stacy Alaimo avers, 'the human is always intermeshed with the more than human world. ${ }^{42}$ Here we see Stephen doing precisely this: his emphasis on seeing the mountains for oneself, on mountaineering as a form of bodily witnessing, allows him to perceive "that "the environment" is not located somewhere out there, but is always the very substance of ourselves. ${ }^{\text {'43 }}$ Thus 'Sunset on Mont Blanc' could be seen as anticipating what would come to be known as deep ecology in providing a model for a biocentric mode of thinking which rejects 'the man-in-the-environment image in favour of the relational, total-field image.'44

\section{Conclusion}

In 'The Symbol', then, Woolf grapples with the issue of holding in balance the ontological complexities of the mountain: the simultaneous sense of interconnectedness (both ecological and familial) and the desire for freedom which the mountain seems to promise to satisfy, even as it calls her back to her father's 'Alpine legacy'. There is, however, reason to suspect that Woolf had started working through these issues long before sitting down to write what is, perhaps, her last short story. ${ }^{45}$ In 1933, following Quentin Bell's diagnosis of tubercular pleurisy, Vanessa Bell accompanied her youngest son to Geneva, where he was to stay at a sanatorium for the next seven months. ${ }^{46}$ Woolf wrote to her nephew during his convalescence, her interest in their Alpine environment evidently stimulated by an earlier letter from Vanessa Bell:

\footnotetext{
${ }^{41}$ Stephen, 'Sunset on Mont Blanc', p. 260. For Hollis's discussion of this passage, see Hollis, 'Leslie Stephen's Science of (Ecological) Ethics', pp. 48-48.

${ }^{42}$ Clark, p. 78; Stacy Alaimo, Bodily Natures: Science, Environment, and the Material Self (Bloomington: Indiana University Press, 2010), p. 2.

${ }^{43}$ Alaimo, p. 4.

${ }^{44}$ Arne Naess, 'The Shallow and the Deep, Long-Range Ecology Movement. A Summary', Inquiry, 16 (1973), 95-100 (p. 95).

45 'The published text of that story ['The Symbol'] is drawn from a typescript with holograph revisions dated 1 March 1941, and thus we are both at the end of Woolf's mountain-related diary entries and within the final days of her life since her suicide comes on the twenty-eighth of that month'. Garrington, p. 83 .

${ }^{46}$ David Pascoe, Airspaces (London: Reaktion Books, 2001), p. 239.
} 
But she says our ancestral mountains rather appeal to her - she begins to feel what father felt novel, solitary, severe. I must come and see them. Do tell me what you think of them. I daresay they change in the dawn and sunset; and one gets to think them more beautiful than any other earth scape. ${ }^{47}$

Judging from this letter alone, Woolf might appear to be the dutiful daughter, eager to follow in her father's footsteps, admiring of his old stomping ground, and ever mindful of his edict that the only way to truly experience the Alps is to 'come and see' them for oneself. Yet this is just what Woolf did not do: she would, in fact, never visit the Alps, and yet, on the basis of the existence of 'The Symbol', it must be inferred that Stephen's anxiety over the inadequacy of language to capture the Alps did not deter her from writing her 'dream story' in the end. Woolf was not a natural mountaineer in the way her father was, and yet in her insistence on the futility of rehashing her 'old experiments' when writing her 'dream story about the top of a mountain', and in her assertion of the necessity of breaking new ground in her writing, one might detect an echo of the fervent scramble to discover new and untested routes of ascent that occurred during the nineteenth century's golden age of Alpinism, in which Stephen was, of course, a significant actor, making nine first ascents in his lifetime. ${ }^{48}$ In order to write a story of the top of a mountain that was truly 'new', however, Woolf would also have to both draw on and define herself against her father's 'Alpine legacy'. Like Lily Briscoe, 'struggling against terrific odds [...] to clasp some miserable remnant of her vision to her breast,' Woolf had to cast aside the various theories and pronouncements on how best to write a mountain, in order to stay faithful to her own 'persistent vision' of the mountain, so that the 'virgin height' - or, one might suggest, Virginia's height - in 'The Symbol' might truly be said to represent 'my mountain top - that persistent vision': a peak of one's own. ${ }^{49}$

\section{Works Cited}

Alaimo, Stacy, Bodily Natures: Science, Environment, and the Material Self (Bloomington: Indiana University Press, 2010).

Briggs, Julia, Reading Virginia Woolf(Edinburgh: Edinburgh University Press, 2006).

\footnotetext{
${ }^{47}$ Virginia Woolf, 'To Quentin Bell', in The Sickle Side of the Moon: The Letters of Virginia Woolf, Volume V: 1932-1935, ed. by Nigel Nicolson and Joanne Trautmann (London: The Hogarth Press, 1979), pp. 244-45 (p. 244) (10 November 1933).

48 Patda Jim, 'The Birth of Alpinism', Climbing (2 November 2009) $<$ https://www.climbing.com/news/the-birth-of-alpinism/\#: :text=More\%20about\%20Leslie\%20Ste phen\%3ASir,life\%20between\%201858\%20and\%201871.> [accessed 19 February 2021].

${ }^{49}$ Woolf, A Writer's Diary, p. 360; Woolf, To the Lighthouse, p. 19.
} 
Carter, Gillian, "Domestic Geography' and the Politics of Scottish Landscape in Nan Shepherd's The Living Mountain', Gender, Place and Culture: A Journal of Feminist Geography, 8, 1 (2001), pp. 25-36.

Clark, Timothy, The Cambridge Introduction to Literature and the Environment (Cambridge: Cambridge University Press, 2011).

Garrington, Abbie, 'The Line that Binds: Climbing Narratives, Ropework and Epistolary Practice', in Modernism and Affect, ed. by Julie Taylor (Edinburgh: Edinburgh University Press, 2015), pp. 75-93.

Hardy, Thomas, 'The Schreckhorn' (June 1897)

http://www.poetryatlas.com/poetry/poem/573/the-schreckhorn.html [accessed 20 February 2021].

Hollis, Catherine W., 'Virginia Woolf as Mountaineer', in Virginia Woolf and the Natural World: Selected Papers of the Twentieth Annual International Conference on Woolf, ed. by Kristin Czarnecki and Carrie Rohman (Liverpool: Liverpool University Press, 2011), pp. 184-90.

— , 'Leslie Stephen's Science of (Ecological) Ethics', in Virginia Woolf and the Common(wealth) Reader: Selected Papers from the Twenty-Third Annual International Conference on Virginia Woolf, ed. by Helen Wussow and Mary Ann Gillies (Clemson: Clemson University Digital Press, 2014), pp. 45-49.

Holroyd, Michael, Lytton Strachey: A Critical Biography, Vol. 1: The Unknown Years (London: Heinemann, 1967).

Jim, Patda, 'The Birth of Alpinism', Climbing (2 November 2009) https://www.climbing.com/news/the-birth-ofalpinism/\#: :text=More\%20about\%2 oLeslie\%20Stephen\%3ASir,life\%2obetween\%01858\%20and\%201871 [accessed 19 February 2021].

Lanone, Catherine, “There is something unspeakable in these outposts” (PI): E. M. Forster's Problematic Poetics of Ascent', in Mountains Figured and Disfigured in the English Speaking World, ed. by Françoise Besson (Newcastle Upon Tyne: Cambridge Scholars Publishing, 2010), pp. 358-71.

Lee, Hermione, Virginia Woolf (London: Vintage, 1997). 
Leopold, Aldo, 'Thinking Like a Mountain', in A Sand County Almanac: And Sketches Here and There (London: Penguin, 2020), pp. 97-99.

Mallory, George Leigh, 'The Mountaineer as Artist', in Climbing Everest: The Complete Writings of George Leigh Mallory, ed. by Peter Gillman (London: Gibson Square, 2010), pp. 15-28.

Naess, Arne, 'The Shallow and the Deep, Long-Range Ecology Movement. A Summary', Inquiry, 16 (1973), pp. 95-100.

Pascoe, David, Airspaces (London: Reaktion Books, 2001).

Shepherd, Nan, The Living Mountain (Edinburgh: Canongate, 2011).

—_ 'Fires', in In the Cairngorms (Cambridge: Galileo Publishers, 2015).

Stephen, Leslie, 'Mr. Whymper's “Scrambles amongst the Alps”, Macmillan's Magazine, 24, 142 (1871), 304-11.

— ' 'Sunset on Mont Blanc', in The Playground of Europe (Cambridge: Cambridge University Press, 2013), pp. 257-78.

—, 'The Regrets of a Mountaineer', in The Playground of Europe (Cambridge: Cambridge University Press, 2013), pp. 303-39.

Woolf, Virginia, The Diary of Virginia Woolf, Volume II: 1920-1924, ed. by Anne Olivier Bell and Andrew McNeilie (London: The Hogarth Press, 1978).

— University Press, 2009), pp. 111-15.

— , 'On Being Ill', in Selected Essays, ed. by David Bradshaw (Oxford: Oxford University Press, 2009), pp. 101-10.

— , 'Reminiscences', in Moments of Being ed. by Jeanne Schulkind (London: Pimlico, 2002), pp. 1-30.

— , 'Sketch of the Past', in Moments of Being, ed. by Jeanne Schulkind (London: Pimlico, 2002), pp. 78-160.

— 'The Symbol', in A Haunted House: The Complete Shorter Fiction, ed. by Susan Dick (London: Vintage, 2003), pp. 282-84.

— To the Lighthouse, ed. by David Bradshaw (Oxford: Oxford University Press, 2006). 
— Vintage, 2008), pp. 76-77 (8 September 1912).

— , 'To Quentin Bell', in The Sickle Side of the Moon: The Letters of Virginia Woolf,

Volume V: 1932-1935, ed. by Nigel Nicolson and Joanne Trautmann (London: The

Hogarth Press, 1979), pp. 244-45 (p. 244) (10 November 1933)

—

(London: Vintage, 2008), p. 14 (February 1904).

, A Writer's Diary: Being Extracts from the Diary of Virginia Woolf, ed. by Leonard Woolf (London: Persephone Books, 2011). 